\title{
Contrasting potential for nature-based solutions to enhance coastal protection services in atoll islands
}

\author{
Virginie K. E. Duvat and Alexandre K. Magnan
}

\begin{abstract}
Based on the study of 107 inhabited islands of the Maldives, we assess to what extent the level of local human disturbance of the coastal protection services provided by the reef-island system influences the potential for nature-based solutions (NBS) to address climate change impacts in atoll contexts. The results show that in 2014-16, 68.2\% of the Maldivian islands (classified Type 3) exhibited a significant human-induced undermining of these services, while respectively $7.5 \%$ and $20.6 \%$ experienced a high (Type 4) and very high (Type 5) level of undermining of these services, whereas hardly any inhabited island shows low levels of undermining (Types 1 and 2). Based on these findings and on our own expertise in atoll environments, we propose a five-pillar adaptation pathway approach for atoll islands: (i) increase ecosystem resilience; (ii) minimise the risk of maladaptation; (iii) facilitate internal relocation; (iv) promote island fortification associated with ground elevation, and (v) support permanent international migration (back-up plan). While the potential for NBS is high for island types 1,2, and 3 (respectively undisturbed, little disturbed, and moderately disturbed islands), it is nil for island types 4 and 5 , where the coastal protection services delivered by the reef-island system are no longer functional. Given that the Maldives Islands are the atoll country exhibiting the highest population densities among atoll countries and territories, our findings indicate that there is still a high potential for NBS in atoll contexts at large.
\end{abstract}

Cite this article: Duvat, V.K.E. \& Magnan, A.K. (2019): Contrasting potential for nature-based solutions to enhance coastal protection services in atoll islands. In: Klöck, C. \& Fink, M. (eds.): Dealing with climate change on small islands: Towards effective and sustainable adaptation? (pp. 45-75). Göttingen: Göttingen University Press. https://doi.org/10.17875/gup2019-1211 


\section{$1 \quad$ Introduction}

Small islands are widely acknowledged to be increasingly at risk of marine flooding and coastal erosion under climate change, as a result of the combination of gradual sea-level rise with more frequent extreme sea levels due to distant-source swells and intensifying intense tropical cyclones, and of the coral decline caused by ocean warming and acidification (Becker et al., 2012; Gattuso et al., 2015; Hoeke, McInnes, \& O'Grady, 2015; Quataert, Storlazzi, van Rooijen, Cheriton, \& van Dongeren, 2015; McInnes, Hoeke, Walsh, O’Grady, \& Hubbert, 2016; Shope, Storlazzi, Erikson, \& Hegermiller, 2016; Beetham, Kench, \& Popinet, 2017; Vitousek et al., 2017; Perry et al., 2018; Storlazzi et al., 2018). Because they are very small (e.g. average size: $0.25 \mathrm{~km}^{2}$ in the Maldives), low-lying (generally $<4 \mathrm{~m}$ in elevation) and mainly composed of unconsolidated reef-derived material (Woodroffe, 2008; McLean \& Kench, 2015), atoll islands are particularly vulnerable to sea-level rise and increasing wave height and energy. Since the late 1990s-early 2000s, the extent to which these islands are liable to be physically destabilised by climate change has become a major global concern, as their destabilisation would eventually cause the disappearance of entire atoll nations (i.e. the Maldives, Marshall Islands, Kiribati, and Tuvalu), due to reef islands constituting the only habitable land in these countries (Barnet \& Adger, 2003; Connell, 2003; McAdam, 2010; Nurse et al., 2014).

Since 2010 , the scientific community has quantitatively assessed multi-decadal (i.e. for the past three or four decades to a century) land area change for 709 islands from 30 atolls in the Pacific and Indian Oceans, thereby providing data on island behaviour under contemporary sea-level rise (Duvat, 2019). Results put an end to the already-sinking-island scenario by proving the persistence of atoll islands and the maintenance of atoll countries' landmass despite higher than average $(1.8 \mathrm{~mm} / \mathrm{yr})$ rates of sea-level rise over the past decades, i.e. rates ranging from $2.0 \pm 0.6 \mathrm{~mm} / \mathrm{yr}$ (on Pingelap and Mokil atolls, the Federated States of Micronesia) to $5.1 \pm 0.7 \mathrm{~mm} / \mathrm{yr}$ (on Funafuti, Tuvalu), with most values lying between 2 and $3 \mathrm{~mm} / \mathrm{yr}$ (Becker et al., 2012). Despite accelerated sea-level rise over the past decades, only $11.4 \%$ of the 709 sample islands decreased in size, while $15.5 \%$ increased and 73.1\% remained stable in area (Duvat, 2019). In addition, all of the islands $>10$ ha experienced either areal stability $(209 / 234$ islands, i.e. $89.3 \%)$ or expansion (25/234 islands, i.e. $10.7 \%$ ), while the islands $<10$ ha underwent more contrasting behaviours, with $65.1 \%$ of these islands experiencing stability, while respectively $17.0 \%$ and $17.9 \%$ showed contraction and expansion. The high instability of very small islands makes some atoll countries, such as the Maldives, particularly vulnerable to climate change (Aslam \& Kench, 2017; Duvat, 2019). More generally, these findings highlight, first, that climate change, particularly sea-level rise, does not constitute the main driver of atoll island change to date, and second, that until now, most atoll islands were able to naturally adapt to ocean-climate related pressures (McLean \& Kench, 2015; Duvat, 2019). 
Simultaneously, scientific advances on the drivers of atoll island change emphasised the major contribution of both climate-related extreme and rapid onset events (especially tropical cyclones and distant-source swells; Scoffin, 1993; Hoeke et al., 2013; Ford \& Kench, 2014; Ford \& Kench, 2016; Duvat, Volto, \& Salmon, 2017) and direct, i.e. local, human disturbances (McLean \& Kench, 2015; Aslam \& Kench, 2017; Duvat, Salvat, \& Salmon, 2017). The latter were found to be a major controlling factor of island change, not only in atoll capitals, e.g. Male' in the Maldives (Naylor, 2015), South Tarawa in Kiribati (Biribo \& Woodroffe, 2013; Duvat, Magnan, \& Pouget, 2013), and Fongafale in Tuvalu (Yamano et al., 2007), but also in rural and even in unsettled islands (Duvat \& Pillet, 2017; Duvat, Salvat, \& Salmon, 2017). In most cases, human-driven changes mainly consisted in land reclamation, carried out to face land shortage, and in coastal infrastructure (airport and harbour) development (Duvat, Salvat, \& Salmon, 2017; Duvat, 2019). For example, in the Maldives, land reclamation caused the highest rates of island and atoll expansion recorded (Aslam \& Kench, 2017; Fallati, Salvini, Strelacchini, \& Galli, 2017), while also causing widespread shoreline armouring (due to the stabilisation of reclaimed areas by seawalls, dykes, and rip-rap) and extended reef degradation (due to the burial or mechanical destruction of reef flats by aggregate mining). Importantly, in most atoll countries and territories, engineered structures aimed at stabilising the shoreline eventually caused island destabilisation (Ford, 2012; Kench, 2012; Duvat, 2013; Duvat et al., 2013; Mann \& Westphal, 2014; Duvat, Salvat, \& Salmon, 2017). This is all the more so as most coastal protection structures are poorly designed and maintained, even in urban islands (Shaig, 2011; Duvat, 2013). Male', which is protected by emerged breakwaters and massive rock revetments along most of its shoreline (Naylor, 2015), is the exception. In atoll environments, the use of hard defence significantly also contributes to the degradation of the reef ecosystem, because the material used to build protection structures is often directly extracted from nearby reef flats and beaches (Biribo \& Woodroffe, 2013; Duvat, 2013), while also undermining the capacity of islands to naturally adjust to ocean-climate related pressures through sediment reorganisation by obstructing reef-to-island sediment transport pathways (McLean \& Kench, 2015; Duvat, 2019). This increases not only current, but also future climate-related risks. In such cases, because they fail to reduce risks and encourage further unsafe development, hard defences can be considered as maladaptive (Temmerman et al., 2013; Logan, Guikema, \& Bricker, 2018).

An alternative to hard defence is to maintain and strengthen the natural coastal protection services delivered by ecosystems, especially the reef ecosystem, to island societies through the use of nature-based solutions (NBS). From a broad perspective, NBS describe "actions to protect, sustainably manage, and restore natural or modified ecosystems that address societal challenges (e.g. climate change, food and water security or natural disasters) effectively and adaptively, while simultaneously providing human well-being and biodiversity benefits" (Cohen-Shacham, Walters, Janzen, \& Maginnis, 2016, p. 2). Despite the recognition of the potential for NBS 
in coral contexts (Narayan et al., 2016; Beck et al., 2018), and more specifically in island contexts (e.g. the Maldives and Seychelles Islands; Ferrario et al., 2014), few local assessments of this potential have been conducted to date. This paper contributes to filling this gap through inventorying and classifying atoll-relevant NBS, and discussing their possible contribution to adaptation pathways for atoll countries and territories. Focusing on sea-level rise-related risks - especially coastal erosion and marine inundation - and based on the most recent literature and a case study (the Maldives), we investigate to what extent the level of human disturbance of the coastal protection services provided by the reef-island system may influence the potential for NBS to address climate change impacts in atoll contexts.

\section{$2 \quad$ Nature-based solutions in atoll contexts}

\subsection{Coastal protection services provided by the reef-island system}

Four major services are delivered by the reef ecosystem to island societies, including the provision of renewable resources (e.g. fish or construction material), biogeochemical services (i.e. nitrogen fixation and $\mathrm{CO}_{2} / \mathrm{Ca}$ control), socio-economic and cultural services (contribution to revenues, local knowledge and beliefs), and biophysical services. The latter are generally referred to as coastal protection services, and include two major functions: (i) wave energy attenuation, and (ii) carbonate sediment supply to the coast (Moberg \& Folke, 1999; Principe et al., 2012; McLean \& Kench, 2015; Elliff \& Silva, 2017).

Both the reef and the reef-derived coastal sedimentary system (i.e. beach or beach-dune system, depending on the setting), hereafter the 'reef-island system', reduce the energy of offshore waves. The reef first plays a major role in wave energy attenuation by causing wave break over the reef crest and wave friction over the reef flat (Principe et al., 2012; Quataert et al., 2015). Ferrario et al. (2014) estimated that reefs are able to attenuate on average $97 \%$ of incoming wave energy and to reduce on average $84 \%$ of the height of incoming waves. This reduces wave run-up, and thereby wave impact at the coast, i.e. the risks of marine inundation and erosion to which island societies are highly exposed (Quataert et al., 2015; Storlazzi et al., 2018). Various attributes control wave energy attenuation by the reef, including its dimensions, depth, topography, and rugosity, that is, roughness. Wave attenuation is higher when the reef is wide and has a contrasting topography and non-smooth surface. Although wave energy dissipation rates are proportional to reef flat width (UNEP-WCMC, 2006; Quataert et al., 2015), 50\% of the energy attenuation occurs along the first $150 \mathrm{~m}$ of the reef flat (Ferrario et al., 2014). In addition, Quataert et al. (2015) showed that wave run-up usually increases with narrow reef flats, steep fore reefs, low reef flat frictions, and high frictions at the fore reef. The nature and condition of coral species growing on the reef flat influence its rugosity. In the extension of the reef flat, the coastal sedimentary system 
(generally a beach system) contributes to absorb and dissipate wave energy. The second biophysical function of the reef, namely sediment delivery to the coast, is influenced by three main factors: (i) reef productivity, which directly reflects reef health; (ii) reef-to-shore sediment transport, driven by wave energy and the maintenance of clear sediment transport pathways and; (iii) the maintenance of accommodation space for sediment deposition at the coast (McLean \& Kench, 2015; Duvat, Magnan, Etienne, Salmon, \& Pignon-Mussaud, 2016). The two biophysical functions exerted by the reef are interlinked, as a healthy reef provides sediments to the coast, which in turn increases wave energy attenuation and thereby contributes to lowering the risks of marine inundation and coastal erosion.

These two coastal protection services are increasingly threatened under global change. Ocean warming and acidification are expected to cause a decrease in coral reef resilience, due to increased coral bleaching and the weakening of the carbonate structure of the reef (Pandolfi, Connolly, Marshall, \& Cohen, 2011; Ateweberhan et al., 2013; Elliff \& Kikuchi, 2015; Gattuso et al., 2015; Hughes et al., 2017). Reef decline would first decrease reef rugosity, as a result of the death and then erosion of corals, which would decrease wave energy dissipation, which would in turn aggravate marine inundation and potentially cause substantial changes to atoll island volume and elevation (Quataert et al., 2015; Storlazzi et al., 2018). Second, it would reduce sediment delivery to the coast, which would accelerate erosion. Simultaneously, accelerated sea-level rise $>+1 \mathrm{~m}$ by 2100 compared to 2000 (e.g. Schaeffer, Hare, Rahmstorf, \& Vermeer, 2012; Kopp et al., 2017), if it did outstrip vertical accretion rates of corals (Montaggioni, 2005; van Woesik, Golbuu, \& Roff, 2015; Perry et al., 2018), would considerably accelerate these processes. The expected decrease in the reef ecosystem resilience will be exacerbated where human disturbances (i.e. pollution, reef mechanical destruction, obstruction of sediment transport, etc.) have already undermined the two abovementioned functions of the reef-island system (Hughes et al., 2017).

These coastal protection services are of utmost importance to atoll islands because of their physical structure (i.e. entirely composed of reef-derived sediments and exposed to waves from all directions because they have a perimeter extending $360^{\circ}$ ) and low elevation (generally $<4 \mathrm{~m}$ ). These islands are highly exposed to marine inundation and induced groundwater lens and soil salinisation, and prone to physical destabilisation, e.g. positional change or rapid change in volume and configuration (Woodroffe, 2008; Hoeke et al., 2013; Smithers \& Hoeke, 2014; McLean \& Kench, 2015; Duvat, 2019). Maintaining or restoring the coastal protection services seems all the more crucial in reef-dependent atoll environments where the reef provides not only physical security to people - as there is no elevated (i.e. $>4-5 \mathrm{~m}$ in general) land to which people can move in the case of a swell event - but also vital food supply. However, over the past decades, increasing human interference with natural processes has at least partly undermined these services on many atoll islands. In particular, atoll countries and territories have increasingly resorted to engineered protection structures to face coastal erosion and 
marine inundation (Nunn, 2009; Kench, 2012; Duvat, 2013). While especially true for capital areas that benefited from international aid-funding - e.g. in Majuro (Ford, 2012), the South Tarawa Urban District (Duvat, 2013), and Male' (Shaig, 2011; Kench, 2012; Naylor, 2015) - these options were also widely deployed in outer, rural islands. The poor design and maintenance of most of these structures (Kench, 2012; Duvat, 2013), however, limited their benefits in terms of better protecting island communities and lowering coastal risks. Even where these structures fulfil their functions, they contribute to undermining the natural coastal protection services provided by the reef-island system. Longitudinal coastal structures (e.g. seawalls or rip-rap) are indeed widely acknowledged to cause beach loss and to prevent sediment deposition at the coast, which respectively decreases wave energy attenuation and prevents island upwards adjustment to sea-level rise (e.g. McLean \& Kench, 2015). In addition, marine structures such as breakwaters often alter the environmental conditions on which coral growth depends, notably by reducing the beneficial effects of waves on reef flats (e.g. oxygen and nutrient inputs, sediment removal from corals). These structures can also be destroyed by storm waves, therefore failing in providing safety to island communities, as reported in Male' in April 1987 (Cazes-Duvat, 2005; Wadey, Brown, Nicholls, \& Haigh, 2017). Finally, such options generate high maintenance costs that often exceed atoll territories' internal capacities (Nunn, 2009). Many arguments thus converge to promote NBS in atoll contexts.

\subsection{A typology for atoll-relevant NBS}

Given the potential of NBS to both provide responses to climate change challenges (mitigation and adaptation) and address biodiversity loss, climate change, and human development together, they have gained growing attention over the last decade (e.g. Temmerman et al., 2013; Ferrario et al., 2014; Narayan et al., 2016). Recent analyses however remind us that NBS are actually the latest in a long line of approaches to support ecosystems' conservation and management (Nature Editorial, 2017; Nesshöver et al., 2017; Rankovic, Chan, \& Kaurans, 2017). The IUCN distinguishes three main types of NBS, including making better use of existing natural or protected ecosystems, developing sustainable management protocols and procedures for managed or restored ecosystems, and creating new ecosystems (Cohen-Shacham et al., 2016, p. 7). Such a typology being very generic, a more specific approach to coastal protection services in atoll contexts is needed.

Here, we propose a new clustering of NBS for island communities' adaptation. It builds on early works from the IPCC that describe a given system's vulnerability to climate change as a function of its exposure, sensitivity, and adaptive capacity (McCarthy, Canziani, Lear, Dokken, \& White, 2001; Parry, Canziani, Palutikof, van der Linden, \& Hanson, 2007). To act on these sub-components of vulnerability defines the very essence of adaptation and refers to four major areas of action (Magnan, 2018): (i) limiting the exposure of the social-ecological system to the 
climate change-induced hazards; (ii) limiting the sensitivity of the reef system to climate change impacts; (iii) limiting the sensitivity of the human components (e.g. settlement patterns, etc.) of the atoll system to climate change impacts; and (iv) enhancing societal adaptive capacity to climate change. In atoll environments, NBS can be especially useful to address (i) and (ii), with cascading benefits on (iii) and (iv). Noteworthy is that this study only deals with the primary benefits to be expected on (i) and (ii), and considers the wide range of NBS that can both directly and indirectly contribute to strengthening the coastal protection services delivered by the reef system. Based on this, three generic clusters of coastal NBS can be identified according to their primary objective:

- Cluster A-Mitigation of climate-related hazards and their impacts locally-Cluster A refers to NBS that help reduce both the ocean drivers (i.e. relative sea-level rise or ocean acidification) and their impacts, e.g. coastal erosion and marine inundation, on atoll islands. An illustrative example is the protection or planting of mangroves in the intertidal zone, which helps raise the floor and hence attenuate relative sea-level rise. When considering other ocean drivers, the literature reports that pollution reduction (e.g., nutrient inputs, release of organic chemicals and trace metals such as mercury) can limit ocean acidification locally (Gattuso et al., 2018). The restoration of seagrass habitats can also help elevate local mean pH (Manzello, Enochs, Melo, Gledhill, \& Johns, 2012; Anthony, DiazPulido, Verlinden, \& Andersson, 2013).

- Cluster B-Direct intervention for maintaining the coastal protection services delivered by the reef system - Cluster B includes NBS that preserve or enhance the role of the reef system in supporting human adaptation to both extreme and slow onset events (i.e. temporary/permanent erosion and marine inundation). Illustrative examples are beach nourishment, coral reef regeneration, and sand dunes revegetation.

- Cluster C - Indirect protection/ conservation of the coastal protection services delivered by the reef system - Cluster C includes NBS that act more indirectly to preserve or strengthen the coastal protection function of the system, i.e. that aim at either enhancing good environmental conditions for the reef ecosystem and the reefderived coastal sedimentary system, including coastal or intertidal vegetation, or avoiding additional anthropogenic pressures on these components. Illustrative examples are Marine Protected Areas (MPAs), or regulations prohibiting coastal vegetation clearing.

Because these are intertwined clusters, a given NBS could contribute to more than one of them. For example, mangrove replanting can both help mitigate relative sea-level rise (Cluster $\mathrm{A}$ ) and create a vegetated barrier attenuating wave energy and reducing wave height (Cluster B). Table 1 applies this frame to examples of atollrelevant NBS. 
Table 1: Examples of NBS in atoll contexts, according to clusters defined above

\begin{tabular}{|c|c|c|c|}
\hline & \multicolumn{3}{|c|}{ Clusters } \\
\hline & $\mathbf{A}$ & B & $\mathbf{C}$ \\
\hline & 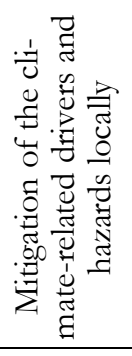 & 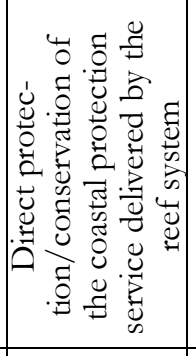 & 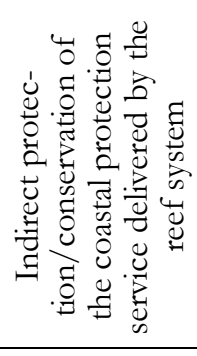 \\
\hline $\begin{array}{l}\text { Mangroves replanting to help raise floor and } \\
\text { then mitigate relative sea-level rise }\end{array}$ & $\mathrm{X}$ & $\mathrm{X}$ & \\
\hline $\begin{array}{l}\text { Restoration of the indigenous coastal vegeta- } \\
\text { tion (marine and terrestrial) to promote beach } \\
\text { ridge formation and coastal feature upward } \\
\text { growth, and therefore reduce the occurrence } \\
\text { of marine inundation and coastal erosion }\end{array}$ & $\mathrm{X}$ & & \\
\hline $\begin{array}{l}\text { Beach nourishment to control the risks of } \\
\text { coastal erosion and marine inundation }\end{array}$ & $\mathrm{X}$ & & \\
\hline $\begin{array}{l}\text { Alternatives to sediment dredging from reef } \\
\text { flats (e.g., low-cost imported building material, } \\
\text { awareness raising on alternatives to seawalls) }\end{array}$ & & $\mathrm{X}$ & $\mathrm{X}$ \\
\hline $\begin{array}{l}\text { Alternatives to intertidal and coastal vegetation } \\
\text { clearing (e.g., low-cost imported material for } \\
\text { cooking) }\end{array}$ & $\mathrm{X}$ & $\mathrm{X}$ & $\mathrm{X}$ \\
\hline $\begin{array}{l}\text { Alternatives to aggregate mining from beaches } \\
\text { and dunes for building and other purposes } \\
\text { (e.g., low-cost imported material, new building } \\
\text { standards using wood) }\end{array}$ & & $\mathrm{X}$ & $\mathrm{X}$ \\
\hline $\begin{array}{l}\text { Marine Protected Areas to support healthy } \\
\text { environmental conditions for the reef ecosys- } \\
\text { tem, marine and coastal vegetation (man- } \\
\text { groves, coastal vegetation, seagrass beds, etc.) }\end{array}$ & & & $\mathrm{X}$ \\
\hline Coral farming & & $\mathrm{X}$ & $\mathrm{X}$ \\
\hline $\begin{array}{l}\text { Assisted evolution and genetic modifications } \\
\text { to enhance corals' adaptive capacities }\end{array}$ & & & $\mathrm{X}$ \\
\hline $\begin{array}{l}\text { Relocation of people and human assets to } \\
\text { restore natural buffers (e.g., coastal retreat to } \\
\text { reverse coastal squeeze trends), with co- } \\
\text { benefits in terms of reducing the exposure of } \\
\text { communities to the risks of coastal erosion } \\
\text { and marine inundation }\end{array}$ & & & $\mathrm{X}$ \\
\hline
\end{tabular}


In most cases, facing the increase of climate change impacts on and human degradation of the atoll system requires the combination of a set of NBS. Furthermore, maintaining or restoring an ecosystem, here the reef system, implies acting on the various components of this system, i.e. (i) the nearshore and intertidal zones, where NBS mainly aim at reducing wave energy (e.g. through building or strengthening buffers, or through the plantation of vegetation); (ii) the coastal zone, which should be left undeveloped to also act as a buffering area; and (iii) in the "hold-theline zone", where buildings and infrastructure would be maintained, but upgraded to meet adequate standards, notably in terms of height and design (e.g. houses on stilts).

Especially in limited capacities contexts, NBS should not be thought of as being opposed (i.e. an alternative) to non-NBS options, but rather as being part of (i.e. combined with other measures) a more comprehensive solution to climate change. For example, the erection of an offshore breakwater in the nearshore zone, which is a hard structure, may guarantee the success of NBS aimed at restoring the various components of the reef-island system. In fact, by dissipating wave energy in the nearshore zone, such a breakwater may contribute to successful coral reef regeneration, vegetation restoration, and beach nourishment. On the other hand, breakwaters can also alter the environmental conditions on which coral growth depends, notably by reducing the beneficial effects of waves on reef flats, i.e., oxygen and nutrient inputs, and sediment removal from corals. This example first illustrates the importance of considering local context-specificities (nature, location, and extent of the environmental components in place, degree of humaninduced disturbances, etc.) as a critical starting point for defining the appropriate balance between various options. Second, it raises a sensitive question: when are NBS the most promising options, and when do they become less effective? The next sections use the case of the Maldivian inhabited islands to answer this question.

\section{Undermining of the coastal protection services by human activities in the inhabited islands of the Maldives}

The assessment of change in atoll island land area, although essential to capture island behaviour, does not constitute a sufficient basis to design adaptation measures, because it has three major limitations. First, it masks the diversity of island situations. For example, islands that exhibited an increase in size may not have the same adjustment capacity in the face of ocean-climate related changes. Island growth can be driven either by human intervention (e.g. land reclamation), or by natural processes. While in the latter case islands may still have the capacity to adjust, in the former case they may not, due to the disruption of natural dynamics by land reclamation, as the latter generally causes a change in island configuration, the obstruction of sediment transport pathways, and aggregate extraction 
from intertidal areas. Second, by focusing on island size, such an assessment does not document the real threats posed to inhabited islands that concentrate most human assets in a comprehensive way. Third, it provides no or limited indication of the potential undermining by direct (i.e. local) human disturbances of the coastal protection services delivered by the reef-island system. In order to address these limitations and capture the potential for NBS in atoll contexts, we conducted a nation-wide assessment of recent island change in the Maldives, using this country as illustrative of atoll contexts. Here, we focus on inhabited islands, and assess change in both island land area (which may be human-driven) and the degree of undermining of the coastal protection services provided by the reef-island system by human disturbances. These two variables are complementary to properly understanding an island's vulnerability to climate change and based on this, to designing island-specific adaptation measures.

\subsection{Methodological background}

\section{Assessing changes in island siz̨e}

The assessment is based on multi-date image analysis, using high resolution satellite images freely provided by Google Earth from the 2004-06 and 2014-16 time periods. Image availability and quality allowed assessing areal change for 107 inhabited islands out of 188 (i.e. 56.9\%), including Male', the country's capital, and Hulhumale, an artificial island still under reclamation and expected to host $\sim 150,000$ inhabitants by 2020 (Naylor, 2015). Because they are distributed among the two Maldivian atoll chains extending from north to south, and because they include all island sizes (from 3.1 to 693 ha), the sample islands are representative of the situation of Maldivian inhabited islands.

\section{Assessing the degree of undermining of coastal protection services by buman activities}

As a reminder, the coastal protection services delivered by the reef-island system include incoming wave energy attenuation and sediment supply to the coast. The latter is driven by reef productivity (i.e. reef health), reef-to-shore sediment transport (controlled by wave energy and the maintenance of clear sediment transport pathways), and the maintenance of accommodation space for sediment deposition at the coast. Despite recent attempts to evaluate the coastal protection service delivered by reefs (e.g. Ferrario et al., 2014; Quataert et al., 2015), such a task remains challenging, due not only to the complexity and variety of this ecosystem (Moberg \& Folke, 1999; Elliff \& Silva, 2017), but also to the great amount of work required if it was to be conducted island by island on a national scale. Yet, as nearby islands may exhibit highly contrasting situations, in regard not only to the exposure of human assets (i.e., people, infrastructures, and buildings), but also to 
shoreline and environmental change (Duvat, Magnan, Wise, et al., 2017; Duvat, 2019), the island scale appears to be a very critical one.

To overcome these constraints, we designed a simple methodology allowing us to assess the degree of undermining of the coastal protection services provided by the reef-island system by direct, i.e. local, human disturbances. This methodology assesses the functionality of this system, i.e. the capacity to naturally respond and adapt to ocean-climate related pressures of its two major components, namely the coastal sedimentary system (extending from the base of the beach to the landward limit of active coastal features) and the reef ecosystem (extending seaward from the base of the beach to the atoll outer slopes). This assessment is based on photointerpretation, using the satellite images that were used to assess island area change. The adaptive capacity of the coastal sedimentary system was assessed based on a single variable, namely shoreline type, given that (i) natural shoreline is required for the maintenance of accommodation space for sediment deposition to occur at the coast (McLean \& Kench, 2015; Duvat, Salvat, \& Salmon, 2017), and (iv) shoreline hardening increases storm wave-induced sediment loss (Duvat et al., 2019; Pillet et al., 2019), which contributes to beach loss and thereby to the annihilation of the wave attenuation service provided by the beach. We classified shoreline type into five categories, i.e. entirely natural $(100 \%$; S1 in Panel A in Figure 1), predominantly natural (i.e. $>50 \%$ of shoreline length; S2), half-natural half-modified (between 45 and $50 \%$ of natural and the same proportion of modified shoreline; S3), predominantly fixed (i.e. > 50\% of fixed shoreline; S4), and entirely fixed (100\%; S5). The coastal protection service delivered by the coastal sedimentary system decreases from S1 to S5, as the degree of undermining of this service by human disturbances increases.

In addition, the functionality and adaptive capacity of the reef ecosystem was assessed by evaluating the extent of direct human pressures that (i) alter reef productivity and (ii) obstruct reef-to-shore sediment transport, including harbours, channel dredging across reef flat, erection of longitudinal marine protection structures (i.e. breakwaters), and sediment dredging from reef flat. Considering that the functionality of the reef ecosystem is inversely proportional to the extent of human disturbances, we distinguished three levels of undermining of the coastal protection service delivered by the reef ecosystem, from 'non-existent to limited' (R1 in Figure 1) to 'high to very high' ( $\mathrm{R} 3$ in Figure 1 ).

Finally, the degree of undermining of the coastal protection services delivered by the reef-island system as a whole was obtained by aggregating these two indicators $(\mathrm{S}+\mathrm{R}$ in Figure 1). This allowed distinguishing five island types, from functional and potentially able to naturally adapt (Type 1, i.e. T1 in Figure 1) to non-functional and unable to naturally adapt (Type 5, i.e. T5 in Figure 1). These five types correspond to various degrees of undermining of the coastal protection services delivered by the reef-island system: no undermining (Type 1), limited undermining (Type 2), moderate undermining (Type 3), high undermining (Type 4), and very high undermining (Type 5). Figure 2 provides real-world examples of these five types, using ex- 
amples from the Maldives Islands. T1, T2, T3, T4, and T5 correspond to the five island types illustrated in Figure 1.

\section{Modification of the CPS delivered by the coastal sedimentary system}

Variable: shoreline type (S)

(S1). Entirely natural $=$ No modification

(S2). Predominantly natural $=$ Limited modification

(S3). Half-natural/half-modified = Substantial modification

(S4). Predominantly fixed $=$ Very substantial modification

(S5). Entirely fixed = Complete modification

2. Degree of undermining of the CPS delivered by the reef ecosystem

Variable: extent of human pressures exerted on the reef ecosystem $(R)$

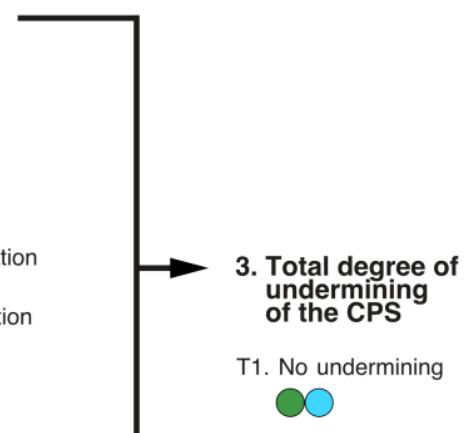

T2. Limited undermining

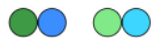

T3. Moderate undermining

$\infty 000$

T4. High undermining

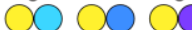

(R1). No to limited human pressure

T5. Very high undermining

(R2). No more than 1 harbour basin + potentially other disturbances (sediment or channel dredging, marine structure) $=$ Moderate pressure

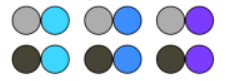

(R3). More than 1 harbour basin + other disturbances (sediment or channel dredging, marine structure) = High to very high pressure

Figure 1: Methodology used to assess the degree of undermining of the coastal protection services (CPS) provided by the reef-island system by local human disturbances in atoll environments 

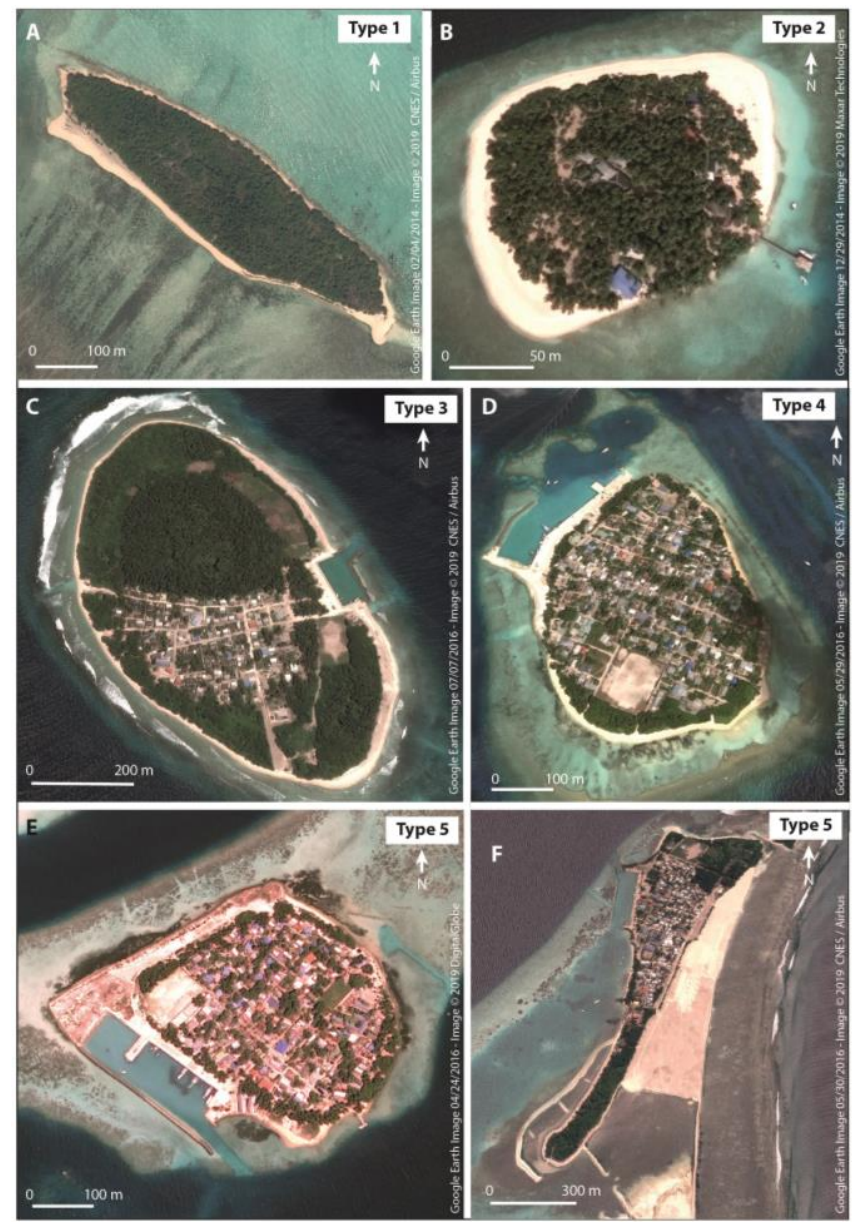

Figure 2: Illustrative example of the five island types highlighting the contrasting degree of undermining of the coastal protection services (CPS) provided by the reef-island system by human activities in the Maldives (source: Duvat \& Magnan, 2019).

A: Maafinolhu Island, Ihavandhippolhu Atoll, illustrates the situation of an undisturbed island (Type 1). B: Kudabados Island, North Kaafu Atoll, shows the situation of an island exhibiting limited undermining of the CPS by human activities (Type 2). C: Hirimaradhoo, Haa Alifu-Noonu Atoll, shows a significant undermining of the CPS, especially on its eastern coast (Type 3). D: Rasdhoo Island, Rasdhoo Atoll, illustrates a substantial undermining of CPS (Type 4), as a result of extensive shoreline modification and armouring, reef degradation, and sediment transport obstruction, due to the establishment of a harbour on its northern side and to the erection of breakwaters on its eastern side. Panels E (Fieeali Island, Faafu Atoll) and F (Muli Island, Meemu Atoll) show a very substantial undermining of CPS (Type 5), as a result of island artificial expansion, still in operation on F, 
extensive shoreline armouring, and extensive reef flat mechanical destruction due to harbour establishment, boat channel, and sediment dredging.

\subsection{Synthetic results}

\section{Change in island size}

The results indicate that over the past decade (i.e. between 2004-06 and 2014-16), none of the 107 study inhabited islands underwent a reduction in size. Importantly, while $41.1 \%$ of them (i.e. 44 islands) remained stable in area, 58.9\% (i.e. 63) increased in size. The latter underwent high rates of expansion, with respectively $47.6 \%, 27.0 \%$, and $25.4 \%$ of these 'growing islands' exhibiting growth rates ranging from 3 to $10 \%, 10$ to $25 \%$, and more than 25\% (Table 2). Although the period of analysis considered here is shorter than the one considered in abovementioned shoreline change studies (i.e. decadal vs. multi-decadal), the results confirm that the majority of inhabited islands, far from undergoing a reduction in land area, expanded, and in this case very rapidly. The highest rates $(>10 \%)$ were however due to land reclamation, which was generally carried out for urbanisation or infrastructure construction purposes, and with consequences on the remaining potential for NBS.

Table 2: Change in inhabited island land area in the Maldives between 2004-06 and 2014-16

\begin{tabular}{r|r|r|r}
\hline \multirow{2}{*}{ Change in land area } & No. of & \multicolumn{2}{|c}{ Percentage } \\
\cline { 3 - 4 } islands & $\begin{array}{c}\text { Related to the total } \\
\text { no. of islands }\end{array}$ & $\begin{array}{c}\text { Related to the no. of } \\
\text { islands in each land } \\
\text { area change category }\end{array}$ \\
\hline Decrease $(\leq-3 \%)$ & 0 & 0.0 & 0.0 \\
\hline Relative stability $( \pm 3 \%)$ & 44 & 41.1 & 100.0 \\
\hline Increase $(\geq 3 \%)$ & & & 47.6 \\
$3 \leq \mathrm{x}<10 \%$ & 30 & 28.0 & 27.0 \\
$10 \leq \mathrm{x}<25 \%$ & 17 & 15.9 & 4.8 \\
$25 \leq \mathrm{x}<50 \%$ & 3 & 2.8 & 12.7 \\
$50 \leq \mathrm{x}<100 \%$ & 8 & 7.5 & 7.9 \\
$\mathrm{x} \geq 100 \%$ & 5 & 4.7 & 100.0 \\
\hline Total increase & 63 & 58.9 & $/$ \\
\hline Total & 107 & 100.0 & \\
\hline
\end{tabular}

Human-driven undermining of the coastal protection services of the reef-island system

The results (Figure 3) show that Maldivian inhabited islands generally fall within types 3 to 5 , therefore exhibiting a moderate to very high level of undermining of 
the coastal protection services provided by the reef-island system by direct human disturbances. In 2014-16, 73 islands (68.2\%) exhibited a moderate human-induced undermining (T3) of these services, while respectively $8(7.5 \%)$ and $23(21.5 \%)$ islands experienced a high (T4) and very high (T5) level of undermining (Figure 3, Panel A). Of note, these proportions were much lower in 2004-06 (72 islands falling within T3 to T5) compared to 2014-16 (103 islands). Importantly, only 7 islands (compared to 23 in 2014-16) belonged to T5 in 2004-06 (Figure 3, Panel A).

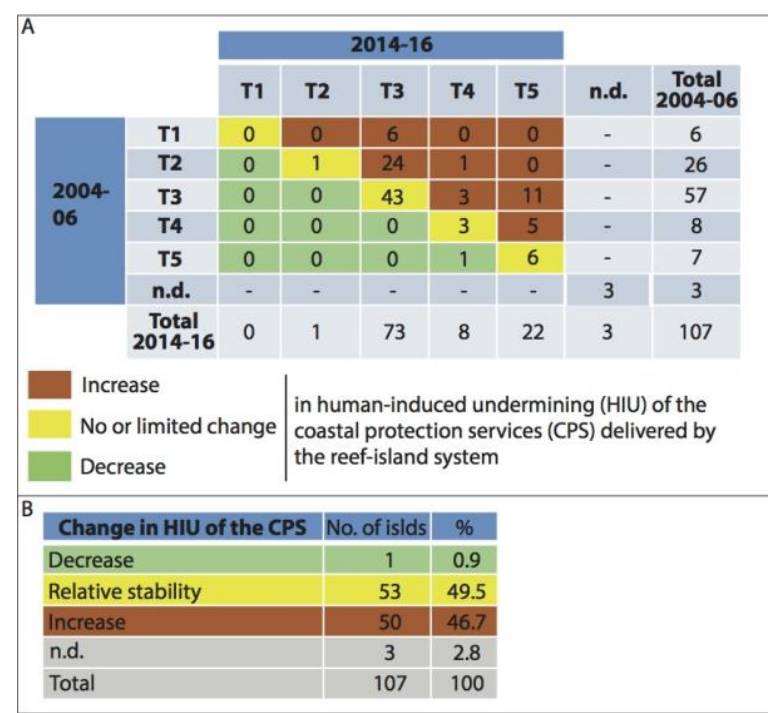

Figure 3: Human-induced undermining (HIU) of the coastal protection services (CPS) delivered by the reef-island system on Maldivian inhabited islands over the past decade. Panel A shows changes in island types (T1 to T5) between 2004-06 and 2014-16. See Figures 1 and 2 for the description of island types. Panel B summarises the results.

These results show a marked increase in human-induced undermining of the coastal protection services delivered by the reef-island system in only one decade (Figure 3, Panel B). They highlight that almost all inhabited islands currently exhibit a moderate to very high level of human-induced degradation of the coastal protection services delivered by the reef-island system to island communities. However, three contrasting situations can be distinguished: (i) T3 islands, representing $68.2 \%$ of inhabited islands, experience a partial degradation of these services, mainly due to the weakening of the functions of the reef ecosystem. On these islands, the reef ecosystem still partly fulfils its functions, and because the shoreline is predominantly natural, it is still able to adjust to ocean-climate related pressures. As a result, the coastal protection services are still functional along most of the 
shoreline of these islands, with the exception of hardened shoreline sections and harbour areas exhibiting disrupted sediment production, transport, and deposition patterns. In contrast, T4 and T5 islands exhibit highly degraded coastal protection services. (ii) T4 islands (7.5\%) experience extended reef flat degradation and shoreline hardening or destabilisation. As a result, along most of the shoreline of these islands, these coastal protection services are no longer delivered by the reef-island system. (iii) Last, on T5 islands (20.6\%), the coastal protection services have been totally undermined by local human disturbances. On these islands, the reef ecosystem has been extensively damaged by the reclamation of the reef flat, and the shoreline is nearly entirely to entirely fixed, depending on cases. Such results suggest first, that the potential for NBS will be highly variable depending on the island type considered, and second, that this potential may rapidly decrease over time, especially on islands exhibiting high human disturbances. These findings advocate for the design of island-specific (i.e. based on island types) adaptation pathways taking into account change in island capacity to adapt.

\section{$4 \quad$ NBS as triggers for atoll adaptation pathways}

The emerging 'adaptation pathway' approach refers to long-term adaptation strategies based upon decision cycles that, over time, sequence a set of possible actions based on alternative external, uncertain developments (Haasnoot, Kwakkel, Walker, \& ter Maat, 2013; Barnett et al., 2014; Wise et al., 2014). Adaptation pathways are fundamentally designed to cope with multiple-source uncertainty (climate change and socio-economic trends, emergence of tipping points, etc.) and hence to enhance systems' flexibility (Brown, Nicholls, \& Woodroffe, 2014; O’Brien et al., 2012; Noble et al., 2014). In addition, their context-specific nature is widely recognised. To date, applications of the adaptation pathway approach to atoll systems have been little explored. Here, based on our own expertise, we propose a fivepillar pathway (Magnan, 2018). Each of the pillars as well as the role of NBS in their implementation are described in a separate sub-section. Based on these developments, the final sub-section proposes a synthesis of the role of NBS in supporting such an atoll adaptation pathway.

\subsection{A generic adaptation pathway for atoll contexts}

The proposed five-pillar adaptation pathway framework for atolls considers multiple temporal scales and sea-level rise scenarios (Figure 4). While the first three pillars - (i) increase ecosystem resilience, (ii) minimise the risk of maladaptation, (iii) facilitate internal relocation - deal with short-to-medium-term strategies with expected long-term benefits, the two last ones - (iv) island fortification associated with ground elevation, and $(v)$ permanent international migration - address medi- 
um-to-long-term worst-case scenarios and must be considered, especially $(v)$, as forming a back-up plan.

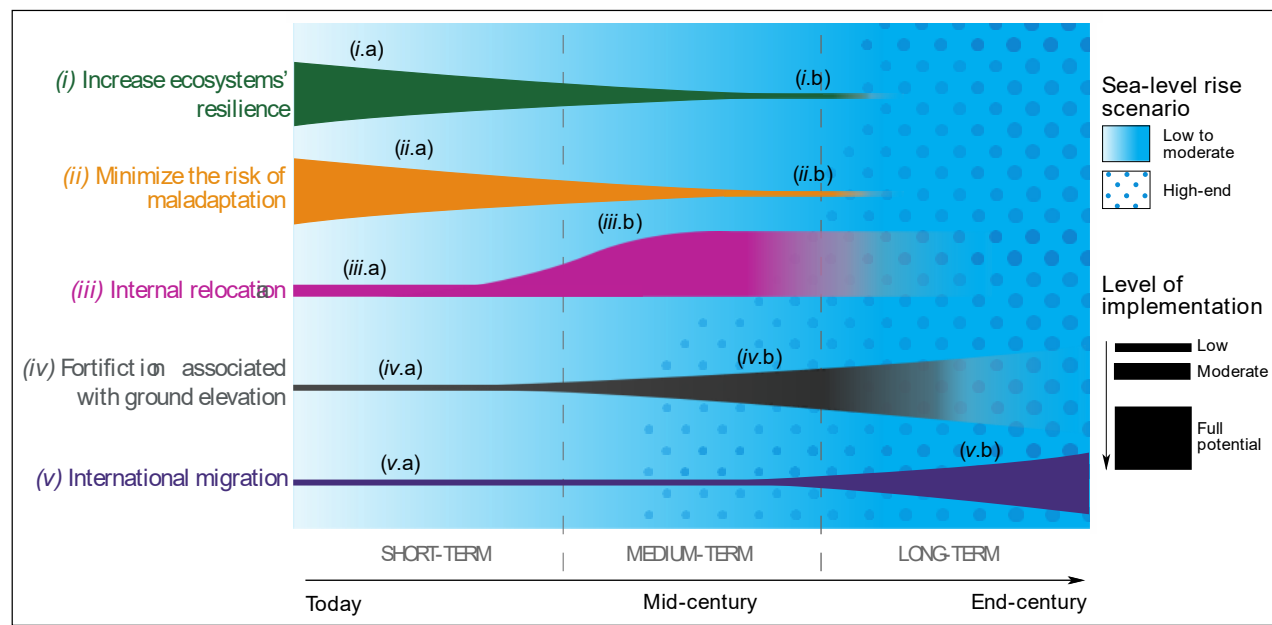

Figure 4: A five-pillar adaptation pathway framework for atoll countries to cope with sea-level rise over the $21^{\text {st }}$ century. In this figure, sea-level rise is schematised for an approximately $1 \mathrm{~m}$ rise (deeper blue) in global mean sea-level by the end of the century compared to the pre-industrial period, and according to the IPCC Representative Concentration Pathways 8.5 (RCP8.5) high greenhouse gas emission scenario. The blue dots represent far higher sea-level rise scenarios (e.g. $>2 \mathrm{~m}$ ), as suggested by very recent studies on ice-melting in Antarctica (DeConto \& Pollard, 2016; Kopp et al., 2017) and/or in the case of the reaching of tipping points. Symbols (i.a) to (v.b) describe various stages of implementation of the (i) to (v) pillars (see main text). The thickness of the drawings therefore describes the theoretical level of implementation of each pillar. It goes from thin lines in the case of a low level of implementation to very thick lines in the case of a full implementation. Colours becoming transparent indicate the progressive obsolescence of the pillar, i.e. its decreasing ability to continue providing solutions to address sea-level rise and ocean change impacts in general. Of note, this figure does not consider the variability of the level of implementation of each pillar from one island or atoll to another and according to diversified local-to-national context-specificities. As a result, full implementation of pillar (i), for example, could refer to different potentials in different case studies.

In Figure 4, symbols (i.a) to (v.b) describe various stages of implementation of the pillars, with (iv.a) to $(v \cdot b)$ constituting a back-up plan in case of worst-case sea-level rise scenarios. (i.a) captures massive short-term actions to protect healthy ecosystems (sand dunes and beaches, coral reefs, mangroves, etc.) and restore already degraded ones. (ii.a) encompasses massive short-term actions to minimise the anthropogenic drivers of vulnerability, e.g. through the control of coastal urbanisation, risk awareness raising, improved access to freshwater and non-imported food 
resources. (i.b) and (ii.b) represent the needed long-lasting efforts to maintain safe environmental and living conditions, for example to continue benefiting from some ecosystem services such as coastal protection and food supply, and to limit anthropogenic contribution to environmental problems. (iii.a) captures the preparation phase of an internal relocation plan considering not only the relocation of people to safer places within the same island or in neighbouring ones, but also options to unclog capital areas through regional development in outer islands, as done in the Maldives, for example. (iii.b) describes the implementation phase of the internal relocation plan, including long-lasting monitoring and adjustment efforts. (iv.a) represents the maintenance of the protected shoreline length as it is today or as planned in the already ongoing projects, without any new major protection works being undertaken. (iv.b) captures the development of ground elevation works preferably on uninhabited islands and/or artificial islands, together with the elaboration of a resettlement plan for urban and rural populations at risk, suggesting links to be made with (iii.a) and (iii.b). (v.a) represents the elaboration of an international migration plan in contemplation of a possible high-end sea-level rise scenario. In accordance with the work undertaken by the international community on the definition of legal bases for international migration, such a plan must address multiple dimensions, from the issues related to the departure of people (e.g., education programmes, funding securing, etc.) to the hosting conditions in the country of destination (e.g. bi- or multi-lateral national agreements, access to living conditions comparable to the ones lost, maintenance of cultural and social values, etc.). Finally, (v.b) describes the implementation of the international migration back-up plan.

\subsection{Increase ecosystem resilience}

Because the reef ecosystem functions (i.e. wave energy dissipation and sediment supply to islands) are indispensable to atoll habitability and are increasingly undermined by both human activities and ocean changes (sea-level rise, ocean warming and acidification), one first unavoidable way to enhance adaptation pathways in atolls consists in maintaining or restoring ecosystem resilience. This pillar applies to the reef-island system as a whole, including the reef ecosystem, reef-derived beach, beach-dune system and its vegetation, and intertidal mangroves. It is all the more valuable that natural islands $>10$ ha that have undisturbed nearshore dynamics are healthy, i.e. were either stable or increased in size over the past decades (Duvat, 2019). The fact that natural ecosystems have up to now at least partly adapted to changing ocean conditions advocates for ecosystem protection and restoration.

It is obvious that the three NBS clusters have a critical role to play in supporting this ecosystem resilience pillar (Figure 5). For instance, as mentioned earlier, mangrove replanting can seriously help mitigate relative sea-level rise impacts at the coast (Cluster A). Also, avoiding clearing the indigenous coastal vegetation belt 
(Cluster B) that usually surrounds atoll islands would help limit storm-induced marine inundation, as indigenous species have proved to be more resistant and resilient than non-indigenous species (Stoddart, 1963, 1965; Duvat et al., 2016; Duvat, Volto, \& Salmon, 2017; Duvat et al., 2019). While coral reef restoration (Cluster B) can also be of direct help, the development of Marine Protected Areas (MPA, Cluster C) can contribute to healthier ecosystems, and hence indirectly support the contribution of the latter to coastal risks reduction now and in the long run. MPA's contribution will however hugely depend on the effectiveness of management systems associated with each MPA, as shown in some recent studies (Abelson et al., 2016; Albright et al., 2016; Cinner et al., 2016).

This pillar is especially relevant for T1 and T2, as they still have healthy and functional ecosystems (Figure 5). It can also play an important role in T3 inhabited islands where the coastal protection services are still delivered by the reef system, although they were degraded by human activities along some shoreline sections. On T3 islands especially, restoring the functionalities of the reef-island system would produce short- and medium-term benefits that would help limit the pathdependencies to human intervention, e.g. the resort to coastal engineered structures to protect exposed human assets. In contrast, because coastal protection services have already been extensively to totally undermined by human activities on T4 and T5 islands, e.g. on atoll capitals (e.g. Male', South Tarawa), this pillar has a more limited potential on these islands.

\subsection{Minimise the risk of maladaptation}

According to Juhola, Glaas, Linnér, and Neset, (2016, p. 139), societal maladaptation is defined "as a result of an intentional adaptation policy or measure directly increasing vulnerability for the targeted and/or external actor(s), and/or eroding preconditions for sustainable development by indirectly increasing society's vulnerability". Minimising the risk of maladaptation strongly relates to limiting the prevailing anthropogenic drivers of vulnerability that operated over the last decades and contributed to past and current maladaptation (Magnan et al., 2016; Duvat, Magnan, Wise, et al., 2017). A classic example is the construction of new buildings in flood-prone areas, e.g. on recently accreted sand spits in South Tarawa Atoll as a result of uncontrolled in-migration from outer rural atolls (Duvat et al., 2013). Because of economic and social path-dependency effects (i.e. spatial concentration of economic activities and modern jobs, education and health opportunities, etc.), reversing recent trends in maladaptive anthropogenic features such as urbanisation, represents an area of 'unavoidable' solutions for adaptation (Magnan \& Duvat, 2018; Magnan, 2018).

Here again, NBS could critically contribute to this end. For example, the consideration of the topography and elevation (Cluster $\mathrm{C}$ ) is a prerequisite for urban planning to avoid the construction of new human assets in flood-prone areas. This can be supported by introducing the climate impacts buffering role of the envi- 
ronment in education programmes (Cluster C). Similar to the previous pillar, making the indigenous vegetation a strong basis for any management and settlement plans (Cluster B) would bring important benefits in terms of coastal risk reduction. Finally, the development of nature-friendly building standards, the design of which considers the natural dynamics of the coastal sedimentary system, can be considered as a NBS. For example, houses on stilts (Cluster C) allow the maintenance of clear sediment transport pathways and hence sediment deposition at the coast, with benefits in terms of reducing both coastal erosion and marine inundation (for the latter, due to the upwards growth of coastal features). Building on stilts also reduces the direct exposure of human assets to marine inundation, hence referring to Cluster A.

Because "minimising the risk of maladaptation" allows limiting the exposure of human assets in all atoll contexts, it theoretically applies to all of the Maldivian inhabited island types, from T1 (undisturbed islands) to T5 (very highly disturbed islands that have lost the natural capacity to adapt). NBS contribution to this pillar however varies significantly across island types. For example, few T5 islands have proper coastal defences, i.e. adequately designed, calibrated, and continuous along the shoreline. Male' is an exception, as its entire shoreline was equipped with properly engineered structures following the highly destructive 1987 distant-source swell event (Cazes-Duvat, 2005; Wadey et al., 2017). In such contexts, the potential for NBS remains limited, not to say almost nil in extreme cases such as Male' where the reef ecosystem has been extensively destroyed by land reclamation (Naylor, 2015). Yet, various examples in developing and developed coastal countries demonstrate similar storylines as Male' in 1987, i.e. the failure of massive engineered structures to protect people and human assets, due to low maintenance levels (e.g. New Orleans in the face of Katrina in 2005, France during the Xynthia storm in 2010; Temmerman et al., 2013). Collectively, these insights suggest that coastal protection structures should not be considered as a self-sufficient solution in the face of increased climate pressures, and that where they are not already prominent (T1 to T3 islands in this study), NBS should be considered. Whatever the option, the above advocates for the 'unavoidable' nature of this pillar.

\subsection{Facilitate internal relocation}

Before considering international migration, internal relocation possibilities should be assessed (e.g., Owen, Kench, \& Ford, 2016), as this strategy may first help address the inextricable problems faced by some capital islands before becoming a way to cope with sea-level rise. Noteworthy is that this pillar is highly complementary to the previous one dealing with the risk of maladaptation, as well as that it will necessarily benefit from the first one on maintaining/restoring ecosystem resilience. A key specific point here is that atoll islands have contrasting topographic profiles, making some of them intrinsically more vulnerable to climate-related pressures than others (Woodroffe, 2008). Islands that have higher elevations, that 
are little exposed to tropical cyclones due to their latitudinal location, and that either increased or remained stable in area over the last decades, should especially be considered as potentially offering valuable relocation opportunities, provided that they also meet other requirements (e.g. have freshwater and food resources) and do not raise inextricable land tenure problems. This could be the basis for a settlement plan using all of the NBS clusters, e.g. by settling areas located at the back of the most elevated coasts (Cluster A), maintaining the coastal indigenous vegetation (Cluster B), and using stilts for constructions as much as possible (Cluster C).

As in the case of South Tarawa in Kiribati, capital atolls generally have a high number of rural and uninhabited islands extending in continuity with the densely settled areas that could be, if they met the abovementioned conditions, considered for internal relocation. Furthermore, envisaging the relocation of the people and human assets of these densely populated islands (e.g. 13,000 inhabitants $/ \mathrm{km}^{2}$ on Betio, South Tarawa) on some other islands (either natural, or rural) in the same atoll would provide an opportunity to get out of the inherited path-dependency (i.e., resort to engineered structures to reduce risks, which in turn increases human assets' exposure, due to beach disappearance, and vulnerability as a result of the false sense of security caused by the construction of such structures) caused by the unsustainable development practices of the past decades.

\subsection{Island fortification associated with ground elevation}

In atoll countries having very low-lying and small islands, such as the Maldives (Aslam \& Kench, 2017; Duvat, 2019), the protection of existing settlements and/or internal relocation may require ground elevation and coastal protection by adequate engineered structures. The option of creating such 'safer islands' had incidentally been envisaged by the Government of the Maldives after the December 2004 tsunami, with the Hulhumale' artificial island as a real-life test. Although controversial, this experience suggests that this 'fortification + ground elevation' pillar could constitute an option in the face of this country's specific constraints, including projected sea-level rise and rapid population growth (almost doubling of the population every 25 years over the past decades).

This pillar however requires, first, adequate material extraction sites to be identified to avoid destroying reef flats supporting islands (Cluster $\mathrm{C}$ ), and second, long-run financial and technical international support. That is, it imposes potentially major negative collateral effects on the local environment, as well as a high dependence on external funding. Despite this, it should still be considered as it can offer one of the few available options for already densely populated areas such as the capital islands (e.g. Male'/Hulhumale' in the Maldives), where the space for pillar (i) (see Figure 5) is often low due to already high levels of coastal and marine environmental degradation. It can however largely benefit from the implementation of pillars (ii) and (iii). But as a whole, this pillar offers little room for manoeu- 
vre for NBS. It should be more specifically considered in the future for T4 and T5 Maldivian islands for which other solutions are not appropriate given, first, the high level of degradation of the reef-island system, and second, the high number and crucial importance (i.e. people, buildings, infrastructure) of highly exposed human assets.

\subsection{Permanent international migration}

The permanent international migration of atoll populations option should be considered as a very last resort in case of high-end sea-level rise scenarios (Figure 5). On the ground, international migration of atoll populations remains mostly theoretical. On the one hand, there is still no scientifically based, uncontroversial evidence on the prevailing role of undergoing climate change impacts in people's decision to move abroad permanently (Connell, 2012). On the other hand, no example exists of a country ready to host an entire environmentally displaced nation. Despite this, we argue that this pillar must still be considered as being part of the panel of options for atoll countries, for three main reasons. First, because there is still uncertainty regarding the $21^{\text {st }}$ century in terms of both the future rates of sea-level rise (especially in the second half of the century) and atoll island physical response to changing conditions (including ocean warming and acidification). Second, because even in the case of drastic greenhouse gas emissions mitigation at the global scale in the coming decades, sea level will continue to rise beyond the $21^{\text {st }}$ century (Church et al., 2013), this fact imposing the need to not limit reflections on atoll population future to the next decades only. Third, because latency phenomena in human systems (i.e. in social, decision-making, and economic processes) call for a multi-decadal anticipatory approach. This last point means that the implementation of responses that are compatible with sea-level rise worst-case scenarios needs time to be designed, hence the usefulness, for example, of starting to discuss the legal status of climate refugees from now on and despite scientific controversies (e.g. Yamamoto \& Esteban, 2014). Anticipating international migration is all the more important because it requires concerned communities to have financial means (Oakes, Milan, \& Campbell, 2016) and to be provided with adequate resources in the country of destination (Allen, 2012).

Due to multiple sources of uncertainty, this pillar must thus be considered as a back-up plan rather than a priority strategy. There is however no space for naturebased action here, as NBS apply to the local context and as this back-up pillar precisely consists in leaving such a local context.

The previous sub-sections suggest that while various types of NBS can bring multiple benefits for enhancing societal adaptation and thus reduce long-term vulnerability to climate-related hazards, especially coastal erosion and marine inundation, their potential contribution is and will still be highly variable across space and time (Figure 5). 


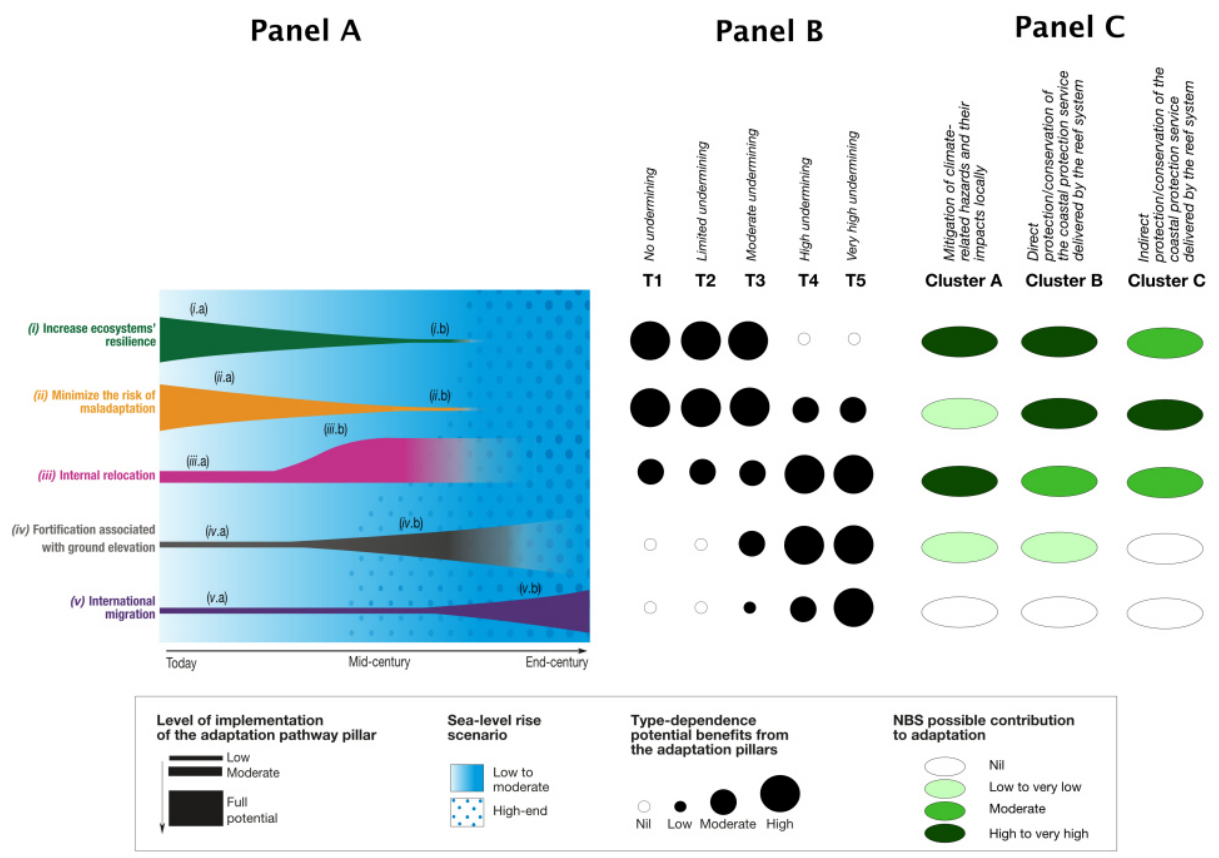

Figure 5: Contrasting potential contribution of nature-based solutions to atoll island adaptation pathways for five distinct island types. See Figure 4 for explanations of Panel A (adaptation pathways). Panel B shows the highly-variable (from nil to high) potential benefits that can be expected from each adaptation pillar for the five island types considered in this study. It highlights the decreasing potential benefits provided by pillars (i) and (ii), from island types T1-T3 to T4-T5. Panel C shows the decreasing contribution of NBS to adaptation from the (i) increase ecosystem resilience and (ii) minimise the risk of maladaptation to the (iii) internal relocation, and then to the (iv) fortification associated with ground elevation and (v) international migration adaptation pillars.

\section{Concluding discussion on the potential contribution of NBS to atoll adaptation pathways}

Using the case of the inhabited islands of the Maldives, we highlighted the variable contribution of NBS to enhance adaptation pathways in atoll islands. Such a potential contribution will however not only depend on island types, but also on three major contextual elements:

- As both the shaping and effectiveness of NBS critically depends on local context specificities, any change in the natural components of the considered system (reef-island system here, which may exhibit differences in configuration from one setting to another) due to the combined impacts of ocean changes, 
i.e. sea-level rise, ocean warming, and ocean acidification, will affect NBS contribution.

- The potential effectiveness of any NBS also critically depends on in-place ecosystem condition and derived morphological features, and will thus be impacted by future levels of human-driven environmental degradation, either in terms of mechanical destruction (e.g. mangroves clearing or aggregate mining from reef flats) or more diffuse degradation (e.g. coastal water pollution), even if some NBS precisely consist of repairing anthropogenic damages (e.g. coral farming or beach nourishment). While NBS can have a critical role today in little-disturbed reef environments, this paper shows that they have a limited potential on significantly to highly disturbed environments.

- Finally, the type of climate scenario that will operate in the coming decades will also affect potential NBS efficacy. Although there is a gap in scientific research on the contribution of NBS under various end-century climate change scenarios, it is arguable that NBS could become ineffective if high-end climate change scenarios are reached in the coming decades.

All of this suggests a possible decreasing importance of NBS contribution as long as we progress into the adaptation pathway pillars sequencing (i.e. from top-left to bottom-right in both Panels $\mathrm{A}$ and $\mathrm{C}$ in Figure 5). The results emphasise that today, in the Maldives, NBS represent a promising area of action in more than two thirds of the 107 sampled inhabited islands, with multiple benefits that will in turn reduce coastal risks and increase NBS effectiveness in the future. As a result, in these inhabited islands (mainly T2 and T3) and in all 'natural' islands (T1), positive feedback loops can still be engaged, with a sequencing of NBS reflecting the first three pillars of the adaptation pathway approach presented in Figure 4 and Figure 5 (i.e. "increase ecosystem resilience", "minimise the risk of maladaptation", "facilitate internal relocation"). However, in already densely populated islands (T4 and T5), the space for NBS is already limited, and the "island fortification associated with ground elevation" pillar must be prioritised. This does not prevent NBS being used to help reduce coastal erosion and marine inundation, but the former will only have limited benefits for risk reduction. Finally, because it consists in leaving atolls, the "permanent international migration" pillar leaves no space for in situ NBS.

\section{Acknowledgements}

This work was supported by the French National Research Agency under the STORISK project (No. ANR-15-CE03-0003). Virginie Duvat was also funded by the INSeaPTION project, which is part of ERA4CS, an ERA-NET initiated by JPI Climate, and funded by FORMAS (SE), BMBF (DE), BMWFW (AT), IFD (DK), MINECO (ES), ANR (FR) with co-funding by the European Union (Grant 
690462). Alexandre Magnan also thanks the ANR programme "Investissements d'avenir" (No. ANR-10-LABX-14-01).

\section{Bibliography}

Abelson, A., Nelson, P. A., Edgar, G. J., Shashar, N., Reed, D. C., Belmaker, J., ... R. Gaines, S. D. (2016). Expanding marine protected areas to include degraded coral reefs. Conservation Biology, 30, 1182-1191.

Albright, R., Anthony, K. R., Baird, M., Beeden, R., Byrne, M., Collier, C., ... Abal, E. (2016). Ocean acidification: Linking science to management solutions using the Great Barrier Reef as a case study. Journal of Environmental Management, 182, 641-650.

Allen, M. G. (2012). Land, identity and conflict on Guadalcanal, Solomon Islands. Australian Geographer, 43(2), 163-180.

Anthony, K. R. N., Diaz-Pulido, G., Verlinden, N., \& Andersson, A. J. (2013). Benthic buffers and boosters of ocean acidification on coral reefs. Biogeosciences, 10, 4897-4909.

Aslam, M., \& Kench, P. S. (2017). Reef island dynamics and mechanisms of change in Huvadhoo Atoll, Republic of the Maldives, Indian Ocean. Anthropocene, 18, 57-68.

Ateweberhan, M., Feary, D. A., Keshavmurthy, S., Chen, A., Schleyer, M. H., \& Sheppard, C. R. C. (2013). Climate change impacts on coral reefs: Synergies with local effects, possibilities for acclimation, and management implications. Marine Pollution Bulletin, 74(2), 526-539.

Barnet, J., \& Adger, W. N. (2003). Climate dangers and atoll countries. Climatic Change, 61, 321-337.

Barnett, J., Graham, S., Mortreux, C., Fincher, R., Waters E., \& Hurlimann, A. (2014). A local coastal adaptation pathway. Nature Climate Change, 4, 1103-1108.

Beck, M. W., Losada, I. J., Menéndez, P., Reguero, B. G., Díaz-Simal, P., \& Fernández, F. (2018). The global flood protection savings provided by coral reefs. Nature Communications, 9, 2186.

Becker, M., Meyssignac, B., Letetrel, C., Llovel, W., Cazenave, A., \& Delcroix, T. (2012). Sea level variations at tropical Pacific islands since 1950. Global and Planetary Change, 80, 85-98.

Beetham, E., Kench, P. S., \& Popinet, S. (2017). Future reef growth can mitigate physical impacts of sea-level rise on atoll islands. Earth's Future, 5, 1002-1014.

Biribo, N., \& Woodroffe, C. D. (2013). Historical area and shoreline change of reef islands around Tarawa Atoll, Kiribati. Sustainability Science, 8, 345-362.

Brown, S., Nicholls R. J., \& Woodroffe, C. D. (2014). Shifting perspectives on coastal impacts and adaptation. Nature Climate Change, 4, 752-755. 
Virginie K. E. Duvat and Alexandre K. Magnan

Cazes-Duvat, V. (2005). Les archipels de l'ouest de l'océan Indien face à l'érosion côtière (Mascareignes, Seychelles, Maldives). Annales de géographie, 4(644), 342-361.

Cinner, J. E., Huchery, C., MacNeil, M. A., Graham, N. A., McClanahan, T. R., Maina, J., ...Mouillot, D. (2016). Bright spots among the world's coral reefs. Nature, 535, 416-419.

Church, J. A., Clark, P. U., Cazenave, A., Gregory, J. M., Jevrejeva, S., Levermann, A., ... Unnikrishnan, A. S. (2013). Sea level change. In T. F. Stocker, D. Qin, G. K. Plattner, M. Tignor, S. K. Allen, J. Boschung, et al. (Eds.), Climate change: The physical science basis. Contribution of Working Group I to the ifth Assessment Report of the Intergovernmental Panel on Climate Cchange (pp. 1137-1216). Cambridge; New York: Cambridge University Press.

Cohen-Shacham, E., Walters, G., Janzen, C., \& Maginnis, S. (Eds.). (2016). Naturebased Solutions to address global societal challenges. Gland, Switzerland: IUCN.

Connell, J. (2003). Losing ground? Tuvalu, the greenhouse effect and the garbage can. Asia Pacific Viewpoint, 44, 89-106.

Connell, J. (2012). Population resettlement in the Pacific: Lessons from a hazardous history? Australian Geographer, 43(2), 127-142.

DeConto, R. M., \& Pollard, D. (2016). Contribution of Antarctica to past and future sea-level rise. Nature, 531(7596), 591-597.

Duvat, V. (2013). Coastal protection structures in Tarawa Atoll, Republic of Kiribati. Sustainability Science, 8, 363-370.

Duvat, V. K. E. (2019). A global assessment of atoll island planform change over the past decades. WIREs Climate Change, wcc.557.

Duvat, V. K. E., \& Magnan A. (2019) (accepted manuscript). Rapid human-driven undermining of atoll island capacity to adjust to ocean climate-related pressures. Nature Scientific Reports.

Duvat, V. K. E., Magnan A., Etienne S., Salmon C., \& Pignon-Mussaud C. (2016). Assessing the impacts of and resilience to Tropical Cyclone Bejisa, Reunion Island (Indian Ocean). Natural Hazards, 83(1), 601-640.

Duvat, V., Magnan, A., \& Pouget, F. (2013). Exposure of atoll population to coastal erosion and flooding: A South Tarawa assessment, Kiribati. Sustainability Science, 8(3), 423-440.

Duvat, V. K. E., Magnan, A. K., Wise, R. M., Hay, J. E., Fazey, I., Hinkel, J., ... Ballu, V. (2017). Trajectories of exposure and vulnerability of small islands to climate change. WIREs Climate Change, e478.

Duvat V. K. E., \& Pillet V. (2017). Shoreline changes in reef islands of the Central Pacific: Takapoto Atoll, Northem Tuamotu, French Polynesia. Geomorphology, 282, 96-118.

Duvat, V. K. E., Pillet, V., Volto, N., Krien, Y., Cécé, R., \& Bernard, D. (2019). High human influence on beach response to tropical cyclones in small islands: Saint-Martin Island, Lesser Antilles. Geomorphology, 325, 70-91. 
Duvat, V. K. E., Salvat, B., \& Salmon, C. (2017). Drivers of shoreline change in French Pacific atoll reef islands. Global and Planetary Change, 158, 134-154.

Duvat, V. K. E., Volto, N., \& Salmon, C. (2017). Impacts of category 5 tropical cyclone Fantala (April 2016) on Farquhar Atoll, Seychelles Islands, Indian Ocean. Geomorphology, 298, 41-62.

Elliff, C. I., Kikuchi, R. K. P. (2015). The ecosystem service approach and its application as a tool for integrated coastal management. Natureza \& Conservaçao, 13(2), 105-111.

Elliff, C. I., \& Silva, I. R. (2017). Coral reefs as the first line of defence: Shoreline protection in face of climate change. Marine Environmental Research, 127, 148-154.

Fallati L., Savini A., Sterlacchini S., \& Galli P. (2017). Land use and land cover (LULC) of the Republic of the Maldives: First national map and LULC change analysis using remote-sensing data. Environmental Monitoring and Assessment, 189, 417.

Ferrario, F., Beck, M. W., Storlazzi, C. D., Micheli, F., Shepard, C. C., \& Airoldi, L. (2014). The effectiveness of coral reefs for coastal hazard risk reduction and adaptation. Nature Communications, 5, 3794.

Ford, M. (2012). Shoreline changes on an urban atoll in the central Pacific Ocean: Majuro Atoll, Marshall Islands. Journal of Coastal Research, 28, 11-22.

Ford, M. R., \& Kench, P. S. (2014). Formation and adjustment of typhoonimpacted reef islands interpreted from remote imagery: Nadikdik Atoll, Marshall Islands. Geomorphology, 214, 216-222.

Ford, M. R., \& Kench, P. S. (2016). Spatiotemporal variability of typhoon impacts and relaxation on Jaluit Atoll, Marshall Islands. Geology, 44(2), 159-162.

Gattuso, J.-P., Magnan, A., Billé, R., Cheung, W. W. L., Howes, E. L., Joos, F., ... Turley, C. (2015). Contrasting futures for ocean and society from different anthropogenic $\mathrm{CO}_{2}$ emissions scenarios. Science, 349, aac4722.

Gattuso, J.-P., Magnan, A. K., Bopp, L., Cheung, W. W. L., Duarte, C. M., Hinkel, J., ... Rau, G.H. (2018). Ocean solutions to address climate change and its effects on marine ecosystems. Frontiers in Marine Sciences, (5), 337.

Haasnoot, M., Kwakkel, J. H., Walker, W. E., \& ter Maat, J. (2013). Dynamic adaptive policy pathways: A method for crafting robust decisions for a deeply uncertain world. Global Environmental Change, 23(2), 485-498.

Hoeke, R. K., McInnes, K. L., Kruger, J., McNaught, R., Hunter, J., \& Smithers, S. (2013). Widespread inundation of Pacific islands by distant-source wind-waves. Global Environmental Change, 108, 128-138.

Hoeke, R. K., McInnes K. L., \& O’Grady J. G. (2015). Wind and wave setup contributions to extreme sea levels at a tropical high island: A stochastic cyclone simulation study for Apia, Samoa. Journal of Marine Science and Engineering, 3, 1117-1135. 
Hughes, T. P., Barnes, M. L., Bellwood, D. R., Cinner, J. E., Cumming, G. S., Jackson, J. B. C., ... Scheffer, M. (2017). Coral reefs in the Anthropocene. Nature, 546, 82-90.

Juhola, S., Glaas, E., Linnér, B.-O., \& Neset, T.-S. (2016). Redefining maladaptation. Environmental Science \& Policy, 55, 135-140.

Kench, P. S. (2012). Compromising reef island shoreline dynamics: Legacies of the engineering paradigm in the Maldives. In J. A. G. Cooper and O. H. Pilkey (Eds.), Piffalls of shoreline stabilization: Selected case studies (pp. 165-186). Dordrecht: Coastal Research Library 3, Springer Science+Business Media.

Kopp, R. E., DeConto, R. M., Bader, D. A., Hay, C. C., Horton R. M., Kulp, S., ... Strauss, B.H. (2017). Evolving understanding of Antarctic ice-sheet physics and ambiguity in probabilistic sea-level projections. Earth's Future, 5, 1217-1233.

Logan T. M., Guikema S. D., \& Bricker J. D. (2018). Hard-adaptive measures can increase vulnerability to storm surge and tsunami hazards over time. Nature Sustainability, 1, 526-530.

Magnan, A. K. (2018). A theory of adaptation to climate change. From trajectories of vulnerability to adaptation pathways. Habilitation Thesis, University of la Rochelle, France.

Magnan, A. K., \& Duvat, V. K. E. (2018). Unavoidable solutions to coastal adaptation in Reunion island. Environmental Science and Policy, 89, 393-400.

Magnan, A. K., Schipper, E. L. F., Burkett, M., Bharwani, S., Burton, I., Eriksen, S., ... Ziervogel, G. (2016). Addressing the risk of maladaptation to climate change. WIREs Climate Change (Advanced Review), 7(5), 646-665.

Mann, T., \& Westphal, H. (2014). Assessing long-term changes in the beach width of reef islands based on temporally fragmented remote sensing data. Remote Sensing, 6, 6961-6987.

Manzello, D. P., Enochs, I. C., Melo, N., Gledhill, D. K., \& Johns, E. M. (2012). Ocean acidification refugia of the Florida Reef Tract. PLOS ONE, 7, e41715.

McAdam, J. (2010). "Disappearing states", statelessness and the boundaries of international law. In McAdam, J. (Ed.), Climate change and displacement: Multidisciplinary Perspectives (pp. 105-109). Oxford: Hart.

McCarthy, J. J., Canziani, O. F., Lear, N. A., Dokken, D. J., \& White, K. S. (Eds.). (2001). Climate Change 2001: Impacts, adaptation, and vulnerability. Contribution of Working Group II to the Third Assessment Report of the Intergovernmental Panel on Climate Change. Cambridge; New York: Cambridge University Press.

McInnes, K., Hoeke, R. K., Walsh, K. J. E., O’Grady, J. G., \& Hubbert, G. D. (2016). Application of a synthetic cyclone method for assessment of tropical cyclone storm tides in Samoa. Natural Hazards, 80, 425-444.

McLean, R., \& Kench, P. S. (2015). Destruction or persistence of coral atoll islands in the face of $20^{\text {th }}$ and $21^{\text {st }}$ century sea-level rise? WIREs Climate Change wcc. 350 .

Moberg, F., \& Folke, C. (1999). Ecological goods and services of coral reef ecosystems. Ecological Economics, 29(2), $215 \mathrm{e} 233$. 
Montaggioni, L. F. (2005). History of Indo-Pacific coral reef systems since the last glaciation: Development patterns and controlling factors. Earth Science Reviews, 71(1-2), 1-75.

Narayan, S., Beck, M. W., Reguero, B. G., Losada, I. J., van Wesenbeeck, B., Pontee, N., ... Burks-Copes, K.A. (2016). The effectiveness, costs and coastal protection benefits of natural and nature-based defences. PLOS ONE, 11(5), e0154735.

Nature Editorial. (2017). Nature language. The latest attempt to brand green practices is better than it sounds. Nature, 541, 133-134.

Naylor, A. K. (2015). Island morphology, reef resources, and development paths in the Maldives. Progress in Physical Geography, 39(6), 1-22.

Nesshöver, C., Assmuth, T., Irvine, K. N., Rush, G. M., Waylen, K. A., Delbaere, B., ... Wittmer, H. (2017). The science, policy and practice of nature-based solutions: An interdisciplinary perspective. Science of the Total Environment, 579, 1215-1227.

Noble, I., Huq, S., Anokhin, Y. A., Carmin, J., Goudou, D., Lansigan, F. P., Osman-Elasha, B., \& Villamizar, A. (2014). Adaptation needs and options. In V. R. Barros, C. B. Field, D. J. Dokken, M. D. Mastrandrea, K. J. Mach, T. E. Bili, et al. (Eds.), Climate Change 2014: Impacts, adaptation, and vulnerability. Part B: Regional aspects. Contribution of Working Group II to the Fifth Assessment Report of the Intergovernmental Panel on Climate Change (pp. 833-868). Cmbridge; New York: Cambridge University Press.

Nunn, P. D. (2009). Responding to the challenges of climate change in the Pacific Islands: Management and technological perspectives. Climate Research, 40, 211-231.

Nurse, L. A., McLean, R. F., Agard, J., Briguglio, L. P., Duvat-Magnan, V., Pelesikoti, N., ... Webb, A. (2014). Small islands. In V. R. Barros, C. B. Field, D. J. Dokken, M. D. Mastrandrea, K. J. Mach, T. E. Bili, et al. (Eds.), Climate Change 2014: Impacts, adaptation and vulnerability. Part B: Regional aspects. Contribution of Working Group II to the Fifth Assessment Report of the Intergovernmental Panel on Climate Change (pp. 1613-1655). Cambridge, MA: Cambridge University Press.

Oakes, R., Milan A., \& Campbell, J. (2016). Kiribati: Climate change and migration. Relationships between bousehold vulnerability, human mobility and climate change. Report No.20, UNU-EHS, 80 p.

O’Brien, K., Pelling, M., Patwardhan, A., Hallegatte, S., Maskrey, A., Oki, T., ... Yanda, P.Z. (2012). Toward a sustainable and resilient future. In C. B. Field, V. Barros, T. F. Stocker, D. Qin, D. J. Dokken, K. L. Ebi, M. D. Mastrandrea, K. J. Mach, G.-K. Plattner, S. K. Allen, M. Tignor, \& P. M. Midgley (Eds.), Managing the risks of extreme events and disasters to advance climate change adaptation. A Special Report of Working Groups I and II of the Intergovernmental Panel on Climate Change (IPCC) (pp. 437-486). Cambridge; New York: Cambridge University Press.

Owen, S. D., Kench, P. S., \& Ford, M. (2016). Improving understanding of the spatial dimensions of biophysical change in atoll island countries and implica- 
tions for island communities: A Marshall Islands' case study. Applied Geography, $72,55-64$.

Pandolfi, J. M., Connolly, S. R., Marshall, D. J., \& Cohen, A.L. (2011). Projecting coral reef futures under global warming and ocean acidification. Science, 333 (6041), 418e422.

Parry, M. L., Canziani, O. F., Palutikof, J. P., van der Linden, P. J., \& Hanson, C. E. (Eds). (2007). Climate Change 2007: Impacts, adaptation and vulnerability. Contribution of Working Group II to the Fourth Assessment Report of the Intergovernmental Panel on Climate Change, 2007. Cambridge; New York: Cambridge University Press.

Perry, C. T., Alvarez-Filip, L., Graham, N. A. J., Mumby, P. J., Wilson, S. K., Kench, P. S., ... Macdonald, C. (2018). Loss of coral reef growth capacity to track future increases in sea level. Nature, 558, 396-400.

Pillet, V., Duvat, V. K. E., Krien, Y., Cécé, R., Arnaud, G., \& Pignon-Mussaud, C. (2019). Contribution of human disturbances to the variability of the impacts of tropical cyclones Irma, José and Maria (September 2017) on Saint-Barthélemy beaches. Ocean \& Coastal Management, 174, 71-91.

Principe, P., Bradley, P., Yee, S., Fisher, W., Johnson, E., Allen, P., \& Campbell, D. (2012). Quantiffing coral reef ecosystem services. U.S. Environmental Protection Agency, Office of Research and Development, Research Triangle Park, NC. EPA/ 600/R-11/206.

Quataert, E., Storlazzi, C., van Rooijen, A., Cheriton, O., \& van Dongeren, A. (2015). The influence of coral reefs on wave-driven flooding of tropical coastlines. Geophysical Research Letters, 42, 6407-6415.

Rankovic, A., Chan, S., \& Kaurans, Y. (2017). Mise en cuvre des solutions fondées sur la nature dans les politiques climat: Enjeux pour la biodiversité. IDDRI Study, 07/17.

Schaeffer, M., Hare, W., Rahmstorf, S., \& Vermeer, M. (2012). Long-term sea-level rise implied by $1.5{ }^{\circ} \mathrm{C}$ and $2^{\circ} \mathrm{C}$ warming levels. Nature Climate Change, 2, 867-870.

Scoffin, T. P. (1993). The geological effects of hurricanes on coral reefs and interpretation of storm deposits. Coral Reefs, 12, 203-221.

Shaig, M. (2011). Survey of climate change adaptation measures in Maldives. Integration of climate change risks into resilient island planning in the Maldives Project. Ministry of Housing and Environment and United Nations Development Programme.

Shope, J. B., Storlazzi, C. D., Erikson, L. H., \& Hegermiller, C. A. (2016). Changes to extreme wave climates of islands within the Western Tropical Pacific throughout the $21^{\text {st }}$ century under RCP 4.5 and RCP 8.5, with implications for island vulnerability and sustainability. Global and Planetary Change, 141, 25-38.

Smithers, S. G., \& Hoeke, R. K. (2014). Geomorphological impacts of highlatitude storm waves on low-latitude reef islands: Observations of the December 2008 event on Nukutoa, Takuu Papua New Guinea. Geomorphology, 222, 106-121.

Stoddart, D. R. (1963). Effects of hurricane Hattie on the British Honduras reefs and cays, October 30-31, 1961. Atoll Research Bulletin, 95, 1-142. 
Stoddart, D. R. (1965). Re-survey of hurricane effects on the British Honduras reefs and cays. Nature, 207, 589-592.

Storlazzi, C. D., Gingerich, S. B., von Dongeren, A., Cheriton, O. M., Swarzenski, P. W., Quataert, E., ... McCall, R. (2018). Most atolls will be uninhabitable by the mid-21 ${ }^{\text {st }}$ century due to sea-level rise exacerbating wave-driven flooding. Science Advances, 4(4), eaap9741.

Temmerman S., Meire P., Bouma T. J., Herman P. M. J., Ysebaert T., \& De Vriend H.J. (2013). Ecosystem-based coastal defence in the face of climate change. $\mathrm{Na}$ ture, Perspective, 504, 79-82.

UNEP-WCMC. (2006). In the front line: Shoreline protection and other ecosystem services from mangroves and coral reefs. Cambridge, UK: UNEP-WCMC, 33 pp.

van Woesik, R., Golbuu, Y., \& Roff, G. (2015). Keep-up or drown: Adjustment of western Pacific coral reefs to sea-level rise in the $21^{\text {st }}$ century. Royal Society Open Science, 2:150181.

Vitousek S., Barnard P. L., Fletcher C. H., Frazer N., Erikson L., Storlazzi C. D. (2017). Doubling of coastal flooding frequency within decades due to sea-level rise. Nature Scientific Reports, 7, 1399.

Wadey, M., Brown, S., Nicholls, R. J., \& Haigh, I. (2017). Coastal flooding in the Maldives: An assessment of historic events and their implications. Natural Hazards, 89(1), 131-159.

Wise, R., Fazey, I., Stafford Smith, M., Park, S. E., Eakin, H. C., Archer van Garderen, E. R. M., \& Campbell, B. (2014). Reconceptualising adaptation to climate change as part of pathways of change and response. Global Environmental Change, 28, 325-336.

Woodroffe, C. D. (2008). Reef-island topography and the vulnerability of atolls to sea-level rise. Global and Planetary Change, 62, 77-96.

Yamamoto L., \& Esteban M. (2014). Atoll states and international law. Heidelberg: Springer.

Yamano, H., Kayanne, H., Yamaguchi, T., Kuwahara, Y., Yokoki, H., Shimazaki, H., \& Chicamori, M. (2007). Atoll island vulnerability to flooding and inundation revealed by historical reconstruction: Fongafale Islet, Funafuti Atoll, Tuvalu. Global and Planetary Change, 57, 407-416. 